\title{
NATURAL ADMIXTURE AS AN ALTERNATIVE FOR CHEMICAL ADMIXTURE IN CONCRETE TECHNOLOGY: A REVIEW
}

\author{
HERSH FAQE ${ }^{1, *}$ HOSHANG DABAGHH $^{* *}$ and AZAD MOHAMMED ${ }^{* * *}$ \\ ${ }^{*}$ College of Engineering, University of Halabja, , Kurdistan Region-Iraq \\ ${ }^{* * *}$ College of Engineering, University of Kurdistan-Iran \\ **** College of Engineering, University of Sulaimani, Kurdistan Region-Iraq
}

(Accepted for Publication: December 8, 2020)

\begin{abstract}
The use of chemical admixtures in concrete is a common practice in modern construction. Although chemical admixtures improve the properties of concrete but also create leaching problem and they are responsible for environmental pollution. The Impact of chemical admixture on environmental can occur when chemical admixtures are exposed to the environment or when dumping concrete granulate containing admixtures after the demolition of a structure or when concrete granulate is used as gravel replacement in construction and as the concrete admixtures are very readily soluble in water, hence create an environmental problem due to leaching. This paper presents a critical review of several natural materials used in concrete as an admixture that influences the mechanical and durability properties of concrete. This kind of admixtures can be considered as an eco-friendly one with regard the impact on the environment and of low cost compared with the chemical admixture.
\end{abstract}

KEYWORDS: Chemical Admixture, Durability, Mechanical properties, Natural Admixture.

\section{INTRODUCTION}

C hemical admixtures play an important role in the production of sustainable normal concrete with improved mechanical properties and long service life; they are used for various purposes depending on their properties; (Patel and Shah, 2013). Several kinds of chemical admixtures can be used and summarized as plasticizers, accelerators / retarding agents, waterproof additives, air-entraining agents, shrinkage reducing admixture, and others such as corrosion inhibitors and coloring agents (Albayraka et al., 2015). Chemical admixtures are used to influence concrete properties such as strength, flow behavior, resistance to frost and deicing salts sulphate resistance, setting characteristics, pump ability and others, Different Chemical admixtures are extensively used in development of concrete with very low water cement ratio, common types are given in Table 1 with their functions.

hersh.faqe@uoh.edu.iq, h.dabbagh@uok.ac.ir, azad.mohammed@univsul.edu.iq 
Journal of University of Duhok, Vol.23, No.2 (Pure and Eng. Sciences), Pp 301-308, 2020 (Special Issue)

$3^{\text {rd }}$ international conference on recent innovations in engineering (ICRIE) Duhok, September 9-10-2020

Table (1): Different chemical admixture used in concrete (Albayraka et al., 2015)

\begin{tabular}{cc}
$\begin{array}{c}\text { Types of chemical } \\
\text { admixture }\end{array}$ & Function \\
\hline $\begin{array}{c}\text { Super plasticizer } \\
\text { strength and dense concrete. }\end{array}$ & $\begin{array}{c}\text { To reduce the water requirement by } 15 \% \text { to } 20 \% \text { without affecting the workability leading to a high } \\
\text { concreting in cold weather. }\end{array}$ \\
\hline Retarder & To reduce the setting time of concrete, it helps to remove the forms early and therefore is used in \\
\hline Water reducing & To achieve a workability (slump) in the ratio of low-water cement to a certain strength and thus \\
admixture & save cement. \\
\hline Air entraining admixture & $\begin{array}{r}\text { To insert small air bubbles into concrete that act as rollers, they therefore improve workability and } \\
\text { therefore very effective in freeze-thaw cycles as they provide a cushioning effect on the } \\
\text { expanding water in the concreting in cold climate. }\end{array}$ \\
\hline
\end{tabular}

\section{2 - CHEMICAL ADMIXTURES AND ENVIRONMENT}

Common chemical admixtures are used to modify the properties of concrete, which is usually made of polymer; these are oil-based and are non-renewable. Chemical admixture can lead to pollution of environment by production, transport, storage or handling, uses in the concrete, service life of concrete structure, recycling of concrete from demolition and disposal of building waste and residues. From the figure 1.simplified life- cycle of concrete admixture.

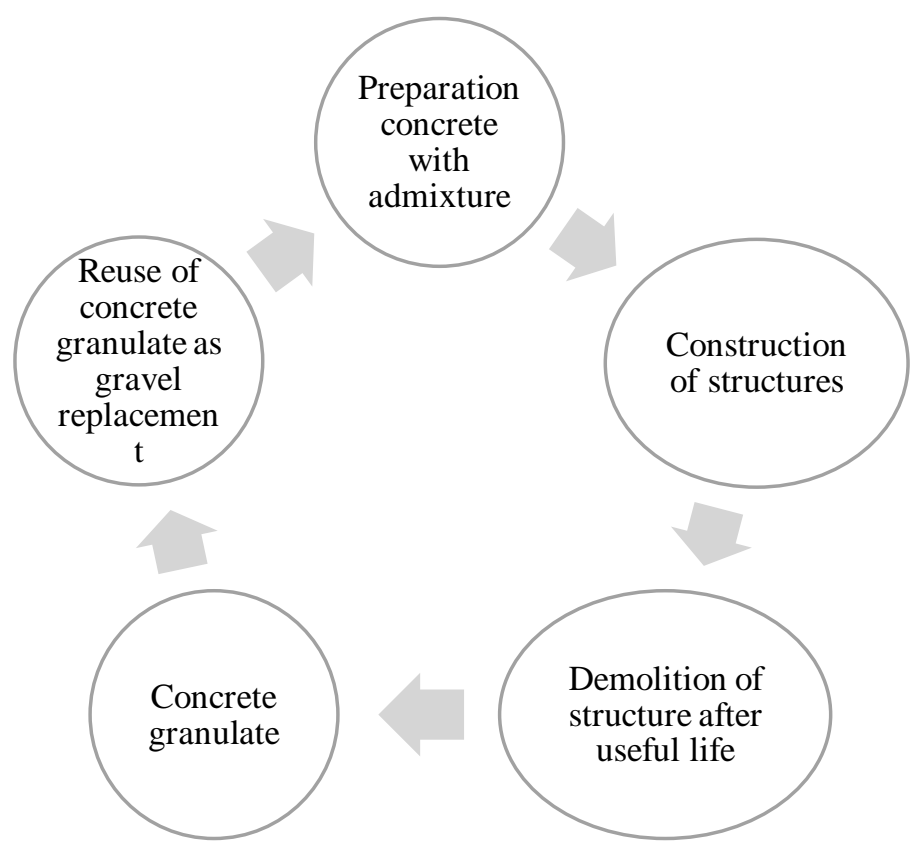

Fig. (1): show Life-cycles of chemical admixtures (Patel et al., 2016)

hersh.faqe@uoh.edu.iq, h.dabbagh@uok.ac.ir, azad.mohammed@univsul.edu.iq 
Superplasticizer is mainly made of water-soluble polymers; these polymers contain naphthalene formaldehyde condensate (SNF) melamine formaldehyde (SMF) Sulfonated condensate, and so on. Moreover, they pose a threat of environmental pollution and harmful to health by releasing chemicals such as formaldehyde (Zhang et al., 2008).Plasticizers and superplasticizers contain a variety of chemicals, some of which have destructive effects on the environment (Collepardi, 1998).
These chemicals in admixture are found in highly water-soluble compounds, and create an environmental problem due to leaching. When they are exposed during concreting or after the demolition of concrete structures or as a result of leaching, if concrete are granulated to be used as coarse aggregate replacement by thus the environment is affected (Patel et al., 2016). figure 2. Show the leaching process of concrete demolition when storing and used as coarse aggregate replacement.

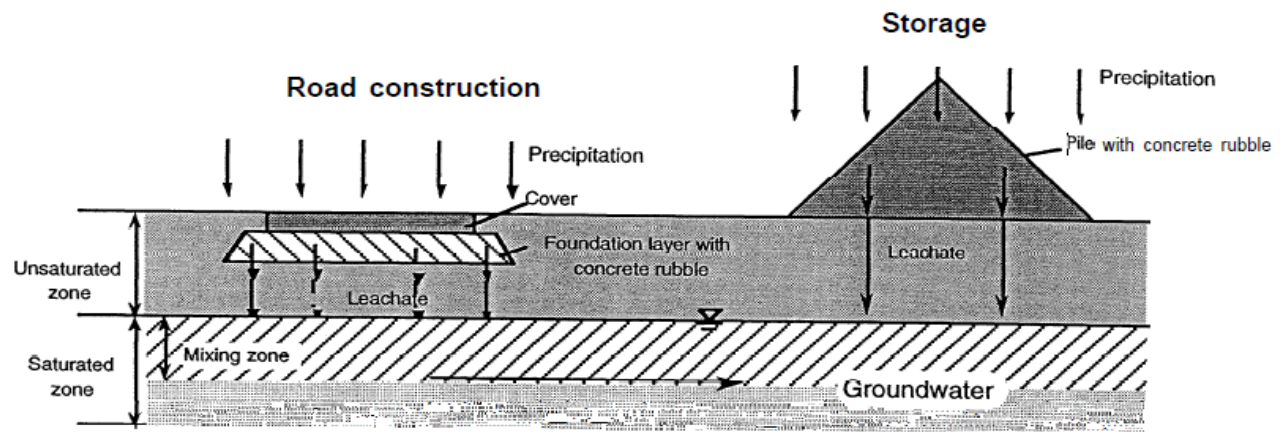

Fig. (2): show leaching process of concrete demolition (Galli R.and Ochs M.)

Chemical admixture has variety of molecules with very different chemical structures and physical properties, the effects of admixture on the properties of concrete are functional groups, chemical configuration, and molecular weight among others that govern the controlling factors (Ouyang, 2009). These chemical admixtures which is oil-based and non-renewable products.

The salts of Lignosulphonates acids, sodium gluconate, citric acid, tartaric acid, hydroxylated carboxylic acids, and various phosphorus compounds such as nitrilotris (methylene) triphosphate are among the chemical admixture used (Cheung, 2011). The calcium chloride and nitrate in the chemical admixture may cause serious problems with the reinforcing bars embedded in concrete members by corrosion the bars. (Aggoun et al., 2008). The use of chemical admixture in concrete is an important role in modern construction. The using of chemical admixtures in concrete reduces water demand and improves the both mechanical and durability properties of concrete. Although the use of chemical admixtures provides better concrete properties, it also pollutes the environment.

Chemical admixture is widely used to modify the durability of concrete for sustainable construction. Further studies on the viscosity-enhancing properties of water-soluble synthetic and synthetic organic polymers have been confirmed (Khayat, 1998; Rolls et al., 1999; Lachemi et al., 2004; Leman and Winnefeld, 2007).Polymers with their long intertwining polymer film are suspected of increasing component mixing. The presence of polymer in the concrete matrix produces concrete with better mechanical properties and 
durability properties (Chang, 2004).

Due to the adverse effects of chemical admixtures on the environment, efforts to find alternative materials that have a similar effect on the concrete properties of concrete are environmentally friendly admixtures. Besides, the use of most natural materials as admixtures, which is waste material, hasn't other benefits (Akindahunsi et al., 2013).

\section{NATURAL ADMIXTURES (N.A) AND EFFECTS}

Some researchers have already been focused on finding an alternative of natural material instead of using chemical admixtures indiscriminately. Organic or natural admixtures can be a viable option because they are so abundant; their production is not very advanced, and makes green construction. With the development of bio-based admixtures that may perform as equally well as oil-based polymers used as admixtures announced their rise, several cases have been shown by researchers and the results showed that have improved the mechanical properties, the durability properties of concrete and it has influenced to the environmental issue. Such as cypress tree extract was used as (N.A.) in the preparation of concrete samples on a constant slump with different doses of extract in water $(5 \%, 10 \%$ and $15 \%)$. The results show that the use of this extract has delayed the setting of cement and can be used with the potential of this extract as a concrete retarder in hot weather (Abraham et al., 2014).

Another extract used was the extract of water Hyacinth with a different ratio $(0,10$, 15 , and $20 \%$ ) to replace water with hydro extract of water Hyacinth. The results show that by increasing the replacement, the compressive strength increases, and also by increasing the replacement, it increases the workability and delays the setting time (Sathya et al., 2014).

Okra extract was used, which was extracted from the plants of the common plant, (Abelmoschus esculent us). The results indicate a decrease in setting time, which indicates the reaction of acceleration hydration, and the addition of this (N.A) also increases the compressive strength behavior of cement mortars [Amrita et al., 2016).

Plant extracts (blue gum extracts) were used in mortar slabs and for different percentages the dose and flow rate, the mortar slabs were prepared that were exposed to the environment, to measure the shrinkage and cracks for different times (5 hours, 3 days, 7 days and 28 days). The results indicate that the use of blue gum extracts reduces shrinkage and cracking due to shrinkage of cement mortar [Abraham Mengesha et al., 2015).

Another (N.A) is Starch that is an available polymer that is found in nature and renewable, inexpensive, and environmentally friendly. The use of starch in various industries is very industries. It is used as a thickener or stabilizer and gelling agent, to regulate consistency, film-forming material for covering seeds, super absorbent, adhesive in the paper industry, drug carrier, in the production of sweeteners and several polygons (Alcazar and Meireles (2015).

Starch from different sources has already been used in various studies to find it's influenced on the properties concrete. Laboratory starch, used at $0.5 \%, 1 \%, 1.5 \%$, and $2.5 \%$ by weight of cement, has an initial and final setting time of $62.50 \%$ and $64.71 \%$, respectively, compared to the control sample. Laboratory starch between 1 and 1.5 percent are more effective. (Sumaiya Afroz et al, 2018).

An anther study of potato starch on aerial

hersh.faqe@uoh.edu.iq, h.dabbagh@uok.ac.ir, azad.mohammed@univsul.edu.iq 
lime-based mortars to examine its effectiveness as a rheological modifier. Depending on the dose (up to $0.30 \%$ lime mortar), it acts as a thickener and above $0.30 \%$ dose, as it behaves plasticizer (A. Izaguirre et al., 2011).

The anther (N.A) used in concrete is natural rubber latex, which can only be produced by the Para rubber plant, with different percentages of natural rubber latex being added to concrete when mixed with water the results showed that the optimal percentage of the natural rubber latex is 0.9 by the weight of cement which improves the strength of concrete (Paul shaji et al., 2017).

Studies that have used gum Arabic as (N.A) to evaluate the effects on the mechanical properties of cement concrete and using dosages of $0.0-1.0 \%$ by weight of cement, the results showed that the optimal strength at a dosage of $0.5 \%$ was obtained, with a percentage increase of 29.5-39.5\% above the control (Elniwa et al., 2018).

Using black gram in the mortar, lightweight concrete, and normal concrete, which has been found to work as an air-entraining agent, has improved the adhesion and hydrophobicity of mortar and concrete (S.Chandra and J.Aavik, 1983).

Lignosulphonates polymer-based waterproof compound (compound 1), acrylic copolymer-based waterproof compound (compound 2), natural polymer-based waterproofing compound (Compound3), which are different waterproof chemicals, are used in concrete to perform performance and impact. It is based on the properties of concrete. Waterproof admixtures were added during the mixing of concrete materials. The optimum percentage of a natural polymer is $1 \%$. Compared to normal concrete, concrete with $0.25 \%$ of compound $1,0.4 \%$ of compound 2 and $1 \%$ of the natural polymer showed more strength and higher slumps (Baby and Mathew, 2016).

Waterproof compounds improve the pores structure of concrete and made concrete denser than normal concrete and showed better mechanical properties than normal concrete. Compared to normal concrete, concrete with a previous ratio showed a decrease in water absorption, porosity, permeability, Sorptivity and strength, and weight loss due to the acid environment. The results of natural polymer-based waterproof concrete comparable to manufactured waterproof concrete, natural polymer were economic and easily available and not harmful to health (Baby and Mathew, 2016).

Molasses (a by-product of the sugar refining process) as (N.A) in concrete, due to the result it has water-reducing and retarding effect on concrete, but the molasses-added cement pastes show expanded setting times even in $0.4 \%$ dosage, and the higher molasses dosage, have the longer setting time (S. B.Pathan and V.V.Singh, .2017).Molasses (sugar) has been used in the England-France channel construction as a retarder in the early, 1990s (Neville, 1995). As well as pure sugar was used in concrete, the results used after 28 days have a maximum compressive strength of $0.06 \%$ sugar and a $\mathrm{w} / \mathrm{c}$ ratio of 0.36 , 0.45 and 0.50 , respectively $48.88 \mathrm{~N} / \mathrm{mm} 2$, $44.44 \mathrm{~N} / \mathrm{mm} 2,40.14 \mathrm{~N} / \mathrm{mm} 2$ (Deva Kate and Colleagues, 2017).

Studies used palm liquor materials in concrete, results show that it improves the combing of honey, compaction and increases the workability of concrete with a maximum of $16.0 \%$ water (Otoko and Ephraim, 2014).

In the anther study, using of Broiler hen egg-white albumen and the yellow yolk was used as (N.A). The studies revealed that $25 \%$ Class $\mathrm{C}$ fly ash blended concrete mix with $0.25 \%$ (N.A) having less water absorption

hersh.faqe@uoh.edu.iq, h.dabbagh@uok.ac.ir, azad.mohammed@univsul.edu.iq 
and porosity, also it has less percentage loss of compressive strength when immersed in $\mathrm{HCL}$ and $\mathrm{H} 2 \mathrm{SO} 4$, it has a lower compressive strength (Ramesh Babuaa et al., 2017).

In other studies, the use of egg albumen, jiggery powder, eggshell \& aloe Vera that utilized as (N.A) in concrete and the results show that with increasing replacement, the workability of concrete has increased with these (N.A) and provides more qualities such as ease of applications, breathability, stickiness, moisture resistance, a natural antiseptic, self- healing, durability, low thermal conductivity, non-combustible, solar production, harmonious balance. Natural environmentally friendly concrete not only modified compressive strength but also modified its durability for centuries (S.Mani Raj et al, 2019).

In other studies using of Opuntia ficus-indica as admixture with the liquid and the powder replacements for both cement-based mortars and cement pastes samples ,results showed increasing in setting time for both liquid and powder replacements and indicating that Opuntia ficus-indica additives could be possible used as retarder admixture (Anne Aquiline et al,2018).

\section{CONCLUSION}

It has been concluded that these studies examined the urgency and validity of focusing on natural admixtures that are environmentally friendly. The results suggest that organic (Natural) admixtures are acceptable options, and the concrete industry should follow this road because of its nature. 1. The use of natural admixture can improve the mechanical properties and durability properties of concrete.

2. Natural admixtures are low cost compared to chemical admixture, and the use of natural admixture with the environment is environmentally friendly.

3. Natural admixture is available from natural obtained. Most of them are wastes that cause environmental issues.

4. The behavior of natural admixture depends on the origin of the plant or resources.

5. Concrete with natural admixture creates green concrete that is friendly with the environment.

\section{REFERENCES}

Abraham M. Woldemariam, Walter O. Oyawa, Silvester O. Abuodha. (2014). Cypress Tree Extract as an Eco-Friendly Admixture in Concrete, International Journal of Civil Engineering and Technology, Volume 5, Issue 6, pp. 25-36.

Abraham Mengesha Woldemariam, Walter O. Oyawa, and Silvester O. Abuodha.(2015).The Use of Plant Extract as Shrinkage Reducing Admixture (SRA) to Reduce Early Age Shrinkage and Cracking on Cement Mortar, International Journal of Innovation and Scientific Research. pp. 136-144.

Aggoun, S., Cheikh-Zouaoui, M., Chikh, N. and Duval, R. (2008). Effect of some admixtures on the setting time and strength evolution of cement pastes at early ages. Construction and Building Materials, 22(2), pp.106-110.

Akindahunsi, A.A., Schmidt, W., Uzoegbo, H.C. \& Iyuke, S.E. (2013). The influence of starches on some properties of concrete. In Proceedings of the 1st ACCTA International Conference on Advances in Cement and Concrete Technology in Africa. Johannesburg, South Africa.

Alcazar-Alay, S.C. and Meireles, M.A.A. (2015). Physicochemical properties, modifications and applications of starches from different botanical sources. Food Science and Technology (Campinas), 35(2), pp.215-236.

Amrita Hazarika, Indranuj Hazarikai, Nabajyoti Saikia. (2016). the effect of a plant based

hersh.faqe@uoh.edu.iq, h.dabbagh@uok.ac.ir, azad.mohammed@univsul.edu.iq 
polymeric material on the fresh and hardened states properties of cement mortar. https://www.researchgate.net/publication/3093 58447.

Amaziah Walter Otuyo, Innocent Koate. (2015). Sugar Cane Juice as a Retarding Admixture in Concrete production, Global Journal of Engineering Research Vol 14, pp. 17-23.

Annu Baby, Jeena Mathew. (2016). Studies on properties of concrete with various Waterproofing compounds, IOSR Journal of Mechanical and Civil Engineering e-ISSN: 2278-1684, p-ISSN: 2320-334X, PP 14-20.

Anne Aquiline, Ruben Paul Borg, Joseph Buhagiar, 2018. The application of Natural Organic Additives in Concrete: Opuntia ficus-indica. Sustainable Concrete: Materials and Structures Materials Science and Engineering 442.

A. Izaguirre, J. Lanas, J.I. Alvarez.( 2014).Effect of a biodegradable natural polymer on the properties of hardened lime-based mortars, https://www.researchgate.net/publication/2503 11630.

A.Sathya, P.B huvaneshware, G, Niranjan, M.Vishveswaran.(2014).Influence of bio admixture on mechanical properties of cement and concrete, Asian Journal of Applied Science ,7(4),pp.205-214.

Chung, D.D.L. (2004). Use of polymers for cement-based structural materials. Journal of materials science, 39(9), pp.2973-2978.

Collepardi, M. (1998). Admixtures used to enhance placing characteristics of concrete. Cement and concrete composites, 20(2-3), pp.103-112.

Deva Kate Arpana Beeranna, Acharya V T, Keerthi Gowda B S,2017, Effect of Sugar on Setting-Time and compressive Strength of Concrete, Mangalore Institute of Technology \& Engineering, Moodbidri,pp.335-337.

Elinwa, Augustine Uchechukwu, Gambo Abdulbasir, Garba Abdulkadir. (2018). Gum Arabic as an admixture for cement concrete production, Construction and Building Materials $176 \mathrm{pp}$. 201-212.
Gulcag Albayraka, Mehmet Canbaza, Ugur Albayraka. (2015).Statistical analysis of chemical admixtures usage for concrete: A survey of Eskisehir city, Turkey, Procedia Engineering 118 pp. 1236 - 1241.

Khayat, K.H. (1998). Viscosity-enhancing admixtures for cement-based materials - an overview. Cement and Concrete Composites, 20(2-3), pp.171-188.

Lachemi, M., Hossain, K.M.A., Lambros, V., Nkinamubanzi, P.C. and Bouzoubaâ, N. (2004). Self-consolidating concrete incorporating new viscosity modifying admixtures. Cement and Concrete Research, 34(6), pp.917-926.

Leemann, A. and Winnefeld, F. (2007). The effect of viscosity modifying agents on mortar and concrete. Cement and Concrete Composites, 29(5), pp.341-349.

Neville, A.M. (1995). Properties of concrete (Vol. 4). London: Longman.

Ouyang, X., Jiang, X., Qiu, X., Yang, D. and Pang, Y. (2009). Effect of molecular weight of sulfanilic acid-phenol-formaldehyde condensate on the properties of cementitious system. Cement and Concrete Research, 39(4), pp.283-288.

Otoko, G. R. and Ephraim, M.E. (2014). Concrete Admixture and Set Retarder Potential of Palm Liquor, European International Journal of Science and Technology, pp.74-80.

Patel, G.K. and Deo, S.V. (2016). Parametric study of natural organic materials as admixture in concrete, International Journal of Applied Engineering Research, 11(9), pp.6271-6277.

Paul shaji, Aswathi K P, Hanna P, Jose K George, Shameer K.( 2017).Effect of Natural Rubber Latex as admixtures in concrete, International Research Journal of Engineering and Technology Vol (4) pp.2031-2034.

Rols, S., Ambroise, J. and Pera, J. (1999). Effects of different viscosity agents on the properties of self-leveling concrete. Cement and Concrete Research, 29(2), pp.261-266.

hersh.faqe@uoh.edu.iq, h.dabbagh@uok.ac.ir, azad.mohammed@univsul.edu.iq 
Ramesh Babuaa T.S., D. Neerajab, Mulugeta Daniel a, Utino Waraboa.(2017).Effect of Natural Admixture on Durability Properties of Conventional and Class C Fly Ash Blended Concrete, American Journal of Engineering Research (AJER), Volume-6, Issue-10, pp-321-333.

S. B.Pathan and V.V.Singh. (2017). Using Molasses in Concrete As A Time Retarding Admixture, International Journal of Engineering Research \& Technology (IJERT), Vol. 6 Issue 11,pp.509-513.

S.Chandra, J.Aavik, 1983, Influence of black gram (natural organic material) addition as admixture in cement mortar and concrete. Cement and concrete research, Volume, May
1983, Pages 423-430.

S.Mani Raj, C.Karthick Raja, M.Karuthapandi, Ms. V.Saranya, 2019, Experimental Study on Eco-Concrete using Natural Admixtures, SSRG International Journal of Civil Engineering (SSRG-IJCE),pp.5-7.

Vatsal Patel and Niraj Shah.( 2013 ).A Survey of High Performance Concrete Developments in Civil Engineering Field, Open Journal of Civil Engineering, 2013, 3, pp.69-79.

Zhang, D.F., Ju, B.Z., Zhang, S.F. and Yang, J.Z. (2008). The study on the synthesis and action mechanism of starch succinate half ester as water-reducing agent with super retarding performance. Carbohydrate Polymers, 71(1), pp.80-84.

hersh.faqe@uoh.edu.iq, h.dabbagh@uok.ac.ir, azad.mohammed@univsul.edu.iq 